\title{
Integrated Eco-Economic Evaluation of Factors in the Regional Model "Environment-Human Health-Quality of Life"
}

\author{
Kundakchyan R.M.
}

\section{Zulfakarova L.F.}

Kazan Federal University, Institute of Management, Economics and Finance, Kazan, 420008, Russia

\section{Doi:10.5901/mjss.2014.v5n24p351}

\section{Abstract}

The article discusses the role of eco-economic factors in the formation of the model "environment - human health - quality of life"; reveals a significant effect of risk factors caused by unfavorable habitat on public health in the case of the Tatarstan Republic (RT); presents the calculation of the integral index for risk factors; ranks the quality of environment in the municipalities of RT by an integral index.

Keywords: Quality of life, eco-economic evaluation of life quality, well-being of the population, risk of environmental hazards, public health.

\section{Introduction}

At the moment the most important tasks in the concept of life quality are the following: to ensure the physical and moral health of society, to provide high quality and environmentally friendly products, to protect the environment, to maintain the resource potential of the region. The main criteria for the quality of life are the indicators of well-being, health, education, housing, quality of products and services, the institutional environment, ecological state of the region, respect for human rights. In fact, in this case we can see that it is a model of interaction among "environment - human health - quality of life." Therefore, this model requires more detailed analysis.

The problem of life quality can not be separated from the common environmental problems in the world and in Russia, because they are closely related not only to economic, but also to social and political decisions. Therefore, no matter what formal or deductive model could have been built based on the relationship among the "environment - quality of life - human health," it will be seriously distorted by the global, state, public, environmental and political instability, as well as by contradictions of exhaustible energy resources and limited economic resources.

The study of environmental problems and their impact on quality of life is reflected in the works of Streimikiene, D., Grasso, M., Canova, L. who investigated the trends in the development of this issue [6]. At the same time the problem of the integrated evaluation of environmental and economic factors has not been resolved yet. In order to solve this problem, we studied the publication of Matarrita-Cascante, D., Haq, R., Zia, U., M., Aganbegian A. Chebykin S. who investigated the evaluation questions and the influence of environmental and economic factors on the environment and quality of life. $[1,4,8,9]$.

\section{The Main Part}

Economic and environmental as well as social interpretation of the problem "environment - human health - quality of Life" seems rather complicated because there are economic, social, institutional and even political aspects of the problem.

The number of research papers devoted to the impact of environmental factors on the health status of population is significant. As a rule, many of the authors are focused on the study of individual components of the ecological system for evaluation of public health or the impact of specific pollutants on human health. Thus, we have identified several factors and conditions that affect both the health of the population and its well-being as a whole. These include, first of all, state and local air quality, drinking water quality, soil contamination factors.

To date, it is proved that there was a direct relationship between the content of specific air pollutants and public health. Air pollutants have negative impact on the health of population, especially children. Inconsistency of children physical development can manifest itself as slower growth, increase or decrease in body weight due to the presence of 
air pollutants such as sulfur dioxide, nitrogen oxides, and carbon monoxide. Increase in air pollution causes the growth in the frequency of respiratory diseases (bronchitis, bronchial asthma, allergic diseases). It is proved that the pollutants in the atmosphere have an adverse effect on pregnancy and fetal development, leading to spontaneous abortions, stillbirths, and congenital malformations.

To study the influence of chemical and bacteriological composition of drinking water on health is of particular interest and importance at the present stage. Variations from the health criteria for water supply can cause such diseases as renal failure, malfunction of cardiac, musculoskeletal and digestive systems.

Soil is the medium which can accumulate significant amounts of pollutants, especially in areas with industrial plants and other sources of pollution. It is known that oil and gas sites can bring macro and micro elements into the soil (chlorides, sulfates, bromine, boron, zinc, copper), and metals (cadmium, arsenic, mercury, lead) which are potentially harmful for the environment and human body. In addition, the property of metals to be absorbed and accumulated in plants is well-known. Pesticides used in agriculture also play a significant part in the pollution of soil. They contain arsenic, mercury, cadmium and other toxic substances. All these greatly affect the health of the population and may cause an increase in infectious diseases, diseases of the gastrointestinal tract, thyroid, and other diseases.

Most scientific papers on this issue concerns the study of the influence of individual factors in eco-economic system. Only in recent years, one can observe a number of research papers devoted to the integrated evaluation of impacts associated with the environment and the characteristics of the response of various population groups. But most of these studies relate to medical and biological problems when studying the quality of life.

Since the systematizing factor of the population well-being is its health, which largely depends on the state of the environment, it becomes necessary to solve the problem of identifying the availability of significant dependency of individual and public health indicators from the risks arising from changes in quality of the ecological system components.

Development of indicators characterizing public health, largely depends on the quality of air, water and soil, which in turn is directly influenced by the effectiveness of measures for the protection of these natural resources. In this regard, we have identified components of the ecological system, forming the ecological environment inhabited by the population, and this became the basis for the calculation of the integral index of risk factors caused by the habitat.

An integral index of risk factors caused by the habitat, as our method suggests, is a complex theoretical rate measured in points. Its calculation is based on the scoring method, according to which the indicators of quality of air, water, soil, having different dimensions, are transferred into points, which allowed us to obtain generalized parameters for 24 indicators characterizing the degree of air, water and soil pollution.

Components of the ecological system in the three conventionally separated areas of oil production are obtained by averaging the data on risk factors of habitat for the period 2007-2013. Among the parameters of risk factors, not all indicators have a negative impact on public health. In particular, the parameter "level of implementation of measures for the air protection, \%" reduces environmental risk due to air quality, and generally has a positive impact on the health of people living in a particular area. In the suggested method such parameters are designated as "indicators, reducing risk factors". They are subtracted from the total scoring of risk factors for the territory (municipality) when calculating the total scoring for a certain group of risk factors (air, water, soil)

Thus, "an integral component of risk factors caused by the habitat" is a complex index, which takes into account the environmental burden on the people living in this area, and include a total scoring of impact of air, water and soil components.

The criterion (index) of risk factors caused by the habitat, is introduced as the sum of all the parameters of the relative degree of influence of each of the indicators on the quality of air, water, soil, measured in points:

$I_{k j}=\sum_{i=1, j=1}^{n, m} \frac{r_{i}}{R_{i}}$

where $I_{k j}$ - integrated assessment value of k-th parameter (air, water, soil - in points) for the j-th site $(i=1 \ldots n$; $j=1 \ldots m) ; r_{i}$ - the absolute value of the i-th parameter affecting the quality of air, water and soil respectively; $R_{i}-$ the average value of this parameter for all units (regions, districts, municipalities, etc.).

Thus, it is the sum of relative quantitative scoring according to the indicator of air, water and soil, that makes an integrated index of risk factors caused by the habitat due to which municipalities are ranked in terms of the values of the integrated index.

It seems interesting to analyze the interaction of the derived index of population well-being, the integrated index of risk factors caused by the habitat, with health indicators of these municipalities in the Republic of Tatarstan, as well as with expenditures on healthcare and the environment per capita. To illustrate the characteristics of these phenomena we have constructed scorecards, reflecting the actual values and the rank of municipalities according to the above values.

Analysis of indicators for averaged scores and the rank of risk factors that threaten the health of the population 
living on the territory of municipalities shows that the quality of soil in a conventionally separated areas and, consequently, in the municipal districts is approximately the same (Table 1).

Table 1. The scores on risk factors threatening the health of the population for 22 municipalities of the Republic of Tatarstan, divided into 3 areas for 2007-2013, in scores

\begin{tabular}{|c|c|c|c|c|}
\hline \multirow{3}{*}{ Components of the environment } & \multicolumn{4}{|c|}{$\begin{array}{l}\text { Scores, in average for } 22 \text { municipalities of the conventionally separated areas ( } \pm \text { standard } \\
\text { deviation) }\end{array}$} \\
\hline & \multirow{2}{*}{ For all municipalities of the indicated areas } & \multicolumn{3}{|c|}{ Specific for municipalities } \\
\hline & & 1 area & 2 area & 3 area \\
\hline Air & $12 \pm 3,9$ & $15,2 \pm 4,2$ & $11,9 \pm 3,2$ & $9,2 \pm 1,4$ \\
\hline Water & $9 \pm 11,6$ & $17,6 \pm 17,1$ & $5,83 \pm 6,6$ & $4,23 \pm 2,6$ \\
\hline Soil & $10 \pm 1,9$ & $9,6 \pm 1,1$ & $10,5 \pm 2,0$ & $9,9 \pm 2,5$ \\
\hline
\end{tabular}

With regard to the quality of air and water by the areas, they as one can see from the table, have significant differences (Table 1). The greatest impact of air pollutant on the quality of the environment is experienced in Almetyevsky, Bugulminsky, and Bavlinsky districts (conventional area 1), Elabuzhsky, Zainsky districts (conventional area 2). The level of air pollution above average is observed in Aznakaevsky, Cheremshansky, Leninogorsky, Yutazinsky districts (area 1), Sarmanovsky, Novosheshminsky, Elabuzhsky (area 2), Mendeleevsky districts (area 3). Low level of air pollution is observed in Muslyumovsky, Nurlatsky, Agryzsky, Mamadyshsky and Alkeevsky disctricts that belong to the second and third conventionally separated areas for oil production. Thus, as expected, and according to studies conducted by different scientists and specialists, high air pollution occurs mainly in the municipalities of the 1st conventional area.

The degree of air pollution is in many ways dependent on the air protection measures and their financing.

It should be noted that the maximum amount of funding is in the territory of South-Eastern municipalities (Table 2).

Table 2. Funding of the environment protection measures in 2007-2013. 3 conventional areas of the Republic of Tatarstan, on average per year, ths. rub.

\begin{tabular}{|c|c|c|}
\hline Area of the municipality & Expenditures on environment protection, per capita & Expenditures on health care, per capita \\
\hline First & 3,59 & 2,3 \\
\hline Second & 3,228 & 2,24 \\
\hline Third & 0,38 & 2,35 \\
\hline
\end{tabular}

As one can see from Table 2, the average cost of measures to protect the environment in the regions has significant differences. Expenditures on the environment protection in the third area are minimum, which is probably due to the small number of emissions into the atmosphere and there was no need to allocate substantial funds to reduce the impact of air pollution on public health. At the same time, the cost of health care per capita living in different areas, as shown by the same table, is nearly the same.

\section{Conclusion}

According to the results of our study concerning the relationship of morbidity and health risk factors in these areas we concluded that there is a significant correlation between public health and risk factors that is reflected by the correlation coefficients. The data show that the risk factors for air and water have a significant correlation with the indicators of primary disease incidence and prevalence of diseases (correlation coefficient $R=0,4-0,5$, the accuracy was confirmed at the level of $p<0,05)$. At the same time the risk factor due to soil pollution, as expected, has a low correlation with the above mentioned indicators (correlation coefficient $R=0,1$, with the same reliability).

Besides, it is worth noting that the indicators of public health in the studied areas have significant statistical difference. Consequently, the quality of components constituting the ecological system for the formation of health indicators is essential. All this is confirmed by parametric values of incidence and prevalence of disease among the population of different regions (Table 3). 
Table 3. The incidence and prevalence of disease among the population in the three areas of municipalities for 20072013, per 1000 of residents (average for the area, with a standard deviation)

\begin{tabular}{|c|c|c|}
\hline Conventional areas & Incidence & Prevalence \\
\hline Area 1 & $741,7 \pm 81,6$ & $1479,0 \pm 191,6$ \\
\hline Area 2 & $675,8 \pm 154,2$ & $1377,7 \pm 416,6$ \\
\hline Area 3 & $602,6 \pm 101,6$ & $1196,9 \pm 237,9$ \\
\hline
\end{tabular}

Morbidity of the population in the third area differs from that of the first and second areas (in the third area, they are lower than in the first and the second) that should be regarded as the impact of intensive pollution of the environment during the intensive production of oil. In addition, the expenditures on healthy environment in the territory of the first area are predominantly (75\%) directed at the protection and use of regional water resources and much less at the protection of soil and air. In this regard, the effect of the human body positive response to the introduction of environment protection measures has to be waited for quite a long time, whereas with the measures to protect the air a positive effect could be achieved much faster.

Heavy pollution of water resources and, consequently, poor water quality (characterized by high scores for this risk factor) is observed mainly in the areas of the first area, except for Elabuzhsky (area 2) Almetyevsky, Yutazinsky, Bugulminsky, Bavly districts. The least dangerous qualitative characteristics of water are in the third area - Alkeevsky districts, and in the second area - in Novosheshminsky, Sarmanovsky, Aksubaevsky districts.

Overall, the analysis of data on the relative total score for all components of the ecosystem (air, water, soil), more specifically the integral index of risk factors caused by the habitat for 22 municipalities, made us conclude that the most harmful from the environmental point of view are Almetyevsky, Yutazinsky, Bugulminsky (area 1), Elabuzhskij, Zainsky (area 2) districts where the scores range from 22.2 to 66.4 points. The most favorable in terms of quality of the ecological environment are Alkeyevsky, Agryzsky, Aktanysh districts (third conventional area) and Nurlatsky, Novosheshminsky (second area of oil production).

Thus, the analysis has revealed a significant adverse effect of environmental factors such as air and water on the quality of people's life in the region, they play a significant role in reducing the level of population well-being living in these territories. The indicators presented and dependencies identified should be considered when developing regional programs for socio-economic development at all levels and evaluating governing bodies in administrative units.

\section{References}

Aganbegyan A. Does Russia need a paradigm shift in the socio-economic development / A. Aganbegyan // Ekonomicheskaya Politika. 2012. - \#6. - pp. 54-66.

Bodrov, O. Main causes of staff labor opportunism in organizations // Life Science Journal, 11(14), 2014, 400-408.

Glushakova O.V. Interdisciplinary approach to the development of the theory and methodology of financial regulation of quality of life reproduction in social and economic systems / O.V. Glushakova, Mikhailov V.V.// Finance and Credit. - 2014. - \#16. - pp. 9-21.

Gadelshina L., Vakhitova T., Grigorieva L. Evaluation of the relationship between integration processes and socio-economic development of regions of Russian Federation under conditions of economic globalization (Based on the Republic of Tatarstan Example) // Mediterranean Journal of Social Sciences (ISSN: 0024-3205), Volume _, 2014. Imprint: ELSEVIER.

Gadelshina L., Vakhitova T. The role and importance of the study of economic subjects in the implementation of the educational potential of education // Procedia-Social and Behavioral Sciences Journal (ISSN: 1877-0428). 2014.

Kandilov V.P. Economic growth and population quality of life in the Republic of Tatarstan / V.P. Kandilov, M. Krasnov, S. Kudryavtseva // Ekonomichesky Vestnik Respubliki Tatarstan. - 2013. - \# 2. - pp. 16-23.

Mokichev Sergei D.- Emerging Markets Queries in Finance and Business,- Tîrgu-Mureș, ROMANIA, 24th-27th, October 2013 Procedia Economics and Finance,- 2013.

Chebykin S.S. Algorithm of defining quality and standard of living of the population as a factor in increasing the efficiency of social and economic policy / S.S. Chebykin // Ekonomika, Statistika, Informatika. Vestnik UMO. - 2011. - \#3. - pp. 160-416.

Safiullin L.N. Fatkhiev A.M. Grigorian K.A. The Triple Helix Model of Innovation / Safiullin L.N. Fatkhiev A.M. Grigorian K.A. // Mediterranean Journal of Social Sciences. Vol. 5, № 18 (2014).

Shekhovtseva L.S. Scientific basis of the concept of the target measure in the level of economic development of the region / L.S. Shekhovtseva // Regioon: Ekonomika i Sotsiologiya. - 2014. - \# 2. - pp. 67-80.

Streimikiene, D. Comparative assessment of environmental indicators of quality of life in Romania and Lithuania// Streimikiene, D.// Economics and Sociology, Volume 7, Issue 1, May 2014, pp. 11-21.

Grasso, M., Canova, L. An assessment of the quality of life in the European union based on the social indicators approach // Grasso, M., Canova, L. //Social Indicators Research, Volume 87, Issue 1, May 2008, pp. 1-25. 
Matarrita-Cascante, D. Changing communities, community satisfaction, and quality of life: A view of multiple perceived indicators // Matarrita-Cascante, D. I/Social Indicators Research, Volume 98, Issue 1, 2010, pp. 105-127

Haq, R., Zia, U. Multidimensional Wellbeing: An Index of Quality of Life in a Developing Economy // Haq, R., Zia, U. //Social Indicators Research, Volume 114, Issue 3, December 2013, pp. 997-1012.

Jia, H.a , Moriarty, D.G.b , Kanarek, N. County-level social environment determinants of health-related quality of life among us adults: A multilevel analysis // Jia, H.a, Moriarty, D.G.b, Kanarek, N.c//Journal of Community Health, Volume 34, Issue 5, October 2009, pp. 430-439. 